\title{
CARLOS V, MADRID Y EL SISTEMA FISCAL CASTELLANO *
}

\author{
DAVID ALONSO GARCÍA
}

Departamento de Historia Moderna Universidad Complutense

\section{RESUMEN}

La formación de una hacienda sujeta a intereses tanto del rey como de las oligarquía constituye uno de los elementos más importantes en el desarrollo del Estado moderno. Este hecho requiere de la creación de una «constitución fiscal» (Brennan, Buchanan) en la que todas la partes cumplen unas normas, implícitas o explícitas, para asegurar el correcto funcionamiento del sistema. Este artículo analiza los beneficios provenientes de la recaudación de alcabalas realizada por la Villa de Madrid en aquiescencia de la Corona. Para ello, realizaremos la comparación entre el montante del encabezamiento con lo ingresado por el receptor de la Villa. Así, intentaremos demostrar que aquellas demasías eran una parte constitutiva de este sistema de beneficios mutuos.

\section{ABSTRACT}

The creation of a tax system linking the interests of the crown as well as the elites constitutes one of the most important developments for the early modern State. It requires the setting up of a «fiscal constitution» in which all parties abide by certain rules, implicit or explicit, to ensure the correct functioning of the system. This article considers the profits arising from the surpluses that resulted from the collection of alcabalas by town councils on agreement of the Crown. This will be done by comparing the amount due to the crown in the encabezamiento with what was actually collected by the

N. de E.: Fecha de recepción del artículo: marzo, 2002.

Fecha de aprobación por el Consejo de Redacción: mayo, 2003.

* A R. García Plaza y L. Montealegre Bachiller, y a todo lo que representan. 
town of Madrid. So, it will be shown that the resulting surpluses were a constitutive part of this mutually beneficial system.

JEL Classification: H11, H71.

\section{INTRODUCCIÓN}

Noche del 30 de agosto de 1540. No fue una noche cualquiera en la vida madrileña. El regidor Diego de Vargas veía cómo se incendiaba su casa en el corazón mismo de Madrid. El inoportuno fuego sorprendió al regidor con un ilustre huésped: el arzobispo de Sevilla, García de Loaisa, quien hubo de arrojarse por la ventana para salvar la vida. La escena era completamente opuesta al regocijo de los toros corridos en junio de este mismo año para deleite de una Corte que por aquel año moraba en Madrid. La casa se encontraba en llamas y hubo de buscarse otro alojamiento para tan insigne «invitado». La estancia elegida fue la casa de don Gutierre de Carvajal, a la postre también familiar de Diego de Vargas. La llegada de principales como Francisco de los Cobos o Hernando de Valdés trajo un mayor consuelo a los perjudicados. A fin de cuentas, su presencia constituía un apoyo evidente tanto en el plano personal como político. Cobos y Valdés, en cambio, no sufrían de modo directo el incendio a pesar de que ellos también moraban en casa de regidores ${ }^{1}$.

La presencia de $\tan$ altas personas no era casual. Sus viajes con la Corte y los Consejos posibilitaban el acceso a las distintas ciudades castellanas. En este año, Madrid era agraciada con el aposento cortesano. Hay que incidir en la importancia simbólica del asunto: eran los regidores de Madrid - muchos de ellos ligados a apellidos que entendían en el gobierno de la Monarquía - quienes prestaban alojamiento a los señores. Desde luego, esta situación constituía un modo de vinculación personal entre los protagonistas, lo cual, traducido a términos políticos, nos presenta una deliciosa metáfora de la relación entre Corona y Reino. El primero mostraba una preeminencia legal incuestionable hasta en los detalles. El segundo, en cambio, ofrecía el necesario mantenimiento.

Grosso modo, este mantenimiento puede identificarse con eso que generalmente conocemos como Hacienda. Del mismo modo que los regidores de Madrid alojaban y alimentaban a los agentes de la Monarquía, Madrid -y el Reino desde una perspectiva más amplia - alimentaba al rey con

${ }^{1}$ El episodio se puede seguir en $\mathrm{B}$ (iblioteca) N(acional), Mss 3825, fol. 87a-87v; León de Pinelo (1971), p. 77. 
dinero $u$ hombres. Pero hay una segunda parte en esta historia: el Reino no «alimentaba» a la Corona sin más, como acto único y unidireccional. Diego de Vargas, el regidor que alojaba a Loaisa, también debía vivir. $\mathrm{Y}$ al arzobispo de Sevilla, por su parte, le interesaba que Vargas viviera para que le proporcionase el sustento. Así, del mismo modo, la Monarquía ligaba su poder al mantenimiento de su propio contrapoder. Es el reflejo de un sistema político asentado en prestaciones recíprocas y desiguales donde la figura de uno no se entiende sin la actuación del otro.

La fiscalidad pasa por ser un espacio idóneo para observar esta relación. La aparición del poder único, característico de los Estados liberales, conllevaba la transformación de la renta en impuesto como característica principal del Estado fiscal que definiera J. Schumpeter. Desde aquí se proyecta el impuesto como característica necesaria de un nuevo sistema político definido como Estado ${ }^{2}$. La capacidad unilateral de coacción que se atribuyó a los distintos monarcas ha sido interpretada como una de las principales muestras de la existencia de un sistema estatal. Distintas matizaciones se vienen haciendo a dicha interpretación. $Y$ con unas sombras proyectadas sobre el concepto Estado también se pone en duda el concepto impuesto a la hora de explicar el carácter último de los tributos ${ }^{3}$. En nuestra opinión, la cuestión de fondo no radica en la existencia o no del impuesto. Antes bien, pensamos que nos encontramos ante un modelo intermedio caracterizado tanto por la existencia de tributos asemejados a impuestos como por tributos asemejados a auxilios ${ }^{4}$.

El presente trabajo intenta demostrar la existencia de una constitución fiscal para Castilla en tiempos de Carlos V. ¿De dónde surge tal concepto? Ya Brennan y Buchanan expusieron cómo una fiscalidad en donde hallásemos unas normas conocidas constituye uno de los elementos capitales para entender los límites del Leviatán. En contra de dichos autores no consideramos que los límites al poder deban venir necesariamente desde la rebaja impositiva ${ }^{5}$. Bien al contrario, la exacción fiscal —que no la presión fiscal- aumentó en tiempos de Carlos $\mathrm{V}$ a partir de los ingresos extraordinarios. ¿Síntoma unívoco del incremento del poder regio? Sí y no, sin que en la lógica del Antiguo Régimen suponga contradicción alguna. El desarrollo de una legislación regia preeminente, un progresivo control protoburocrático de territorio o la extensión de una organización fiscal

${ }^{2}$ Vid. Schulze (1996), pp. 257-276; cfr. Bulgarelli Luckacs (1993).

${ }^{3}$ Cárceles de Gea (2000).

4 Alonso García (1999).

5 Brennan y Buchanan (1980). Esta línea fue seguida por Gómez Álvarez (1996). 
cuyo referente último se encontraba en el propio monarca, demuestran que el poder monárquico se manifestaba con una fuerza desconocida en relación con tiempos anteriores. La clave reside en el cómo. Porque para ejercer este poder el monarca necesitaba necesariamente de su propio contrapoder, identificado en un concepto tan laxo como el de oligarquías ${ }^{6}$. Para extender su propio poder, el rey necesitaba hacer más y más grande a estas oligarquías, lo cual le fortalecía tanto como le debilitaba. Por ello mismo la fiscalidad se convertirá en un espacio antes político que económico controlado por las elites de poder ${ }^{7}$.

¿Y cómo abordar este pacto que beneficiaba tanto a Corona como a Reino? Un elemento sobresaliente de la historia de la Hacienda es la formulación de los tributos como elementos inherentes al gozo y beneficio de quien los controlara ${ }^{8}$. Este elemento tiene una traducción inmediata en las denominadas «sobras» de encabezamiento. Metodológicamente, tratamos de proponer algunos datos, más o menos seriados, que demuestran que tanto el rey como las oligarquías debían resultar beneficiadas para el correcto entendimiento entre ambas esferas de poder. Consideramos este hecho como parte de una constitución fiscal de contenidos más amplios, y que, en concreto, hay que contextualizar en la política sobre servicio y rentas eclesiásticas así como los distintos mecanismos de financiación a partir del recurso a la deuda. Para ello compararemos las cantidades que el rey recibía del encabezamiento de Madrid con lo recaudado por el receptor de la Villa. Asimismo, nos acercaremos a los grandes beneficios que consiguió Madrid por los sistemas de recaudación puestos en marcha. ¿Por qué Madrid? 1561 -fecha del traslado «definitivo» de la Corte a Madrid - consolida unas tendencias que ya funcionaban ${ }^{9}$; tendencias que siempre aluden a la estancia cortesana como fuente del beneficio. Pues bien, desde un punto de vista económico, el beneficio nos lleva al terreno de lo fiscal, en concreto al encabezamiento. La propia presencia de la Corte - ya antes de 1561 - se encontraba dentro de una política que premeditadamente buscaba el beneficio de la oligarquía a partir, entre otros, de los sistemas de recaudación. De otro modo, la oligarquía de

${ }^{6}$ Ruiz Ibáñez (1995); cfr. Hernández (1999).

7 Vid., por constituir dos trabajos de gran influencia, Tracy (1985) y Collins (1988). Para el caso español, Fernández Albadalejo (1992), esp. pp. 248 ss.; Dedieu y Ruiz (1994); Gelabert (1997); Hernández (2001).

${ }^{8}$ Alonso García (1999).

9 Al menos así ocurre en el terreno de la fiscalidad. Vid. Alonso García (en prensa). Cfr. López García (1998). Llevamos a cabo una valoración historiográfica de la «capitalidad» en Alonso García (2001). 
Madrid controlaba su espacio fiscal a cambio de otras contraprestaciones. Algo sabemos de la cuestión para los siglos XVII y XVIII ${ }^{10}$.

\section{HACIENDA REGIA Y ENCABEZAMIENTO}

En primer lugar, de modo breve, hay que dejar bien claras las posiciones teóricas de las cuales partimos. El encabezamiento ha sido tratado como un sistema recaudatorio mediante el cual el rey delegaba el cobro de los impuestos en los concejos. A cambio, las distintas villas y ciudades $-\mathrm{y}$ a partir de 1536 el Reino de manera mancomunada- debían pagar al rey una cantidad prefijada. De este modo, el rey ganaba en seguridad y en un mayor conocimiento y control de la realidad fiscal ${ }^{11}$; mientras el reino veía compensada su posición con una reducción efectiva de la presión fiscal al mismo tiempo que pasaba a controlar los tributos. No constituía una cuestión de transvase de soberanía fiscal, sino mera cuestión administrativa. $Y$ de este modo, los ingresos ordinarios se quedaban en terreno de lo público - identificado con la hacienda del rey - sin necesidad de buscar agentes privados, esto es, los arrendadores de rentas. Para los arrendadores no había delegación administrativa, sino un transvase de la soberanía fiscal. Claro está que esto mismo conllevaba una perfecta definición de los conceptos de público y privado ${ }^{12}$. De ahí que el paso de un sistema a otro marcase un punto de modernización histórica a partir de la forma política del Estado (fiscal).

Ahora bien, hay que tener en consideración que las ciudades y las villas no son las únicas entidades con capacidad para encabezarse. También las personas, o mejor un grupo de personas, entraban en los distintos encabezamientos por menor en los cuales se dividía el encabezamiento de Madrid. Personas que normalmente coincidían en un hecho: pertenecen al mismo oficio por el cual se encabezan ${ }^{13}$. Incluso, también el propio encabezamiento podía conllevar prometidos, esto es, la cantidad abonada a los arrendadores como contraprestación por la recaudación de tributos ${ }^{14}$. Esto nos indica que ambas prácticas no se encuentran tan alejadas unas de otras, al menos con anterioridad a 1536. Además, hay una cuestión

\footnotetext{
${ }^{10}$ Hernández (1995).

"Fortea (2001).

12 Un valioso acercamiento a la definición de ambos conceptos en Bobbio (1992 ${ }^{2}$ ).

13 Alvar (1989), pp. 241 ss.; Asenjo González (1997); Zabala Aguirre (2000), pp. 185 ss.

14 Así al menos ocurre con Guadalajara en 1513, cuyo prometido ascendió a 56.000 maravedís sobre unas rentas encabezadas por 1.806.000. A(rchivo) G(eneral) de S(imancas),
} 
de contabilidad que nos parece bastante esclarecedora al respecto: en las cuentas de los distintos receptores de la Villa de Madrid el encabezamiento no se presenta como un ingreso (cargo), sino como un gasto (data).

$\mathrm{Y}$ !legamos en este punto al concepto de sobras de encabezamiento. Uno de los problemas que ha encontrado una historiografía exclusivamente estatal ha sido la explicación de por qué se recaudaba más de lo que «legalmente» se había de recaudar. Con la percepción de un poder único y homogéneo, encarnación unívoca de Estados, hay que buscar una Hacienda pública unitaria. Así, la bolsa del rey es la única existente y toda polisemia fiscal no constituye sino mera sumisión a la hacienda del rey. De este modo se procede a la identificación de Hacienda como sistema financiero único y controlado desde arriba ${ }^{15}$. La solución, en algunos casos, consistía en cerrar los ojos a los mecanismos de gestión interna de las rentas, terreno que precisamente escapa al control del Monarca. $O$ de otro modo, quedarse con los rendimientos teóricos de los encabezamientos identificando estas cifras con toda la recaudación. Con lo pagado a la Monarquía se acaba el rendimiento fiscal de la renta ${ }^{16}$. Y, sin embargo, es difícil entender una delegación administrativa referida al encabezamiento cuando se «puede comprar [...] al quitar» ${ }^{17}$. De aquí que las alcabalas pasen al Reino en 1536 pese a tener un origen regio. Es de destacar que algunos estudios excepcionales se detienen a explicar qué eran las sobras, identificando éstas como asunto público de los ayuntamientos:

«Constituía una ventaja apreciable las llamadas sobras -excesos sobre la cantidad concertada-, pues que ellas iban a disminuir la obligación contraída en el siguiente año, o el superávit de carácter regional, digámoslo así, de partido, que disminuía a su vez la de la circunscripción administrativa de que se trataba, o la dedicaba a los Concejos respectivos a cubrir atenciones municipales de índole varia. Bien es verdad que lo propio sucedía con los arriendos, por las pujas, con los prometidos; mas siempre la ventaja redundaría en aquel caso en beneficio de la colectividad, y, en el segundo, de un arrendatario" ${ }^{18}$.

Por tanto, se asimilan las sobras a un superávit que servía para costear los gastos públicos de los municipios. Las sobras, según esto, constituyen

E(scribanía) M(ayor) de R(entas), leg. 140. ¿Excepción? Encontramos el mismo caso, entre otros, para Ciudad Real en el año 1517. AGS, EMR, leg. 156.

${ }^{15}$ Las características de los actuales sistemas tributarios en Sainz de Bujanda (199310).

16 Vid., entre otros, Carande $\left(1990^{3}\right)$ y Ulloa $\left(1977^{2}\right)$.

17 A(rchivo) de la V(illa) de M(adrid), Documentos Reales, 4 de febrero de 1529.

${ }^{18}$ Espejo (1928). 


\begin{tabular}{|c|c|}
\hline$A \bar{n} o$ & Recaudación teórica \\
\hline 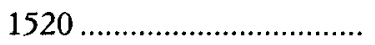 & 3.319 .529 \\
\hline 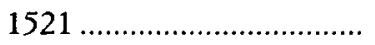 & 3.500 .574 \\
\hline $1522 \ldots \ldots \ldots \ldots \ldots \ldots$ & 3.492 .206 \\
\hline $1523 \ldots$ & 3.486 .729 \\
\hline $1524 \ldots$ & 3.514 .369 \\
\hline $1525 \ldots \ldots \ldots \ldots \ldots$ & 3.543 .465 \\
\hline $1526 \ldots \ldots \ldots \ldots \ldots \ldots$ & 2.626 .215 \\
\hline $1527 \ldots \ldots \ldots \ldots \ldots$ & 2.643 .715 \\
\hline $1528 \ldots \ldots \ldots$ & 2.883 .415 \\
\hline 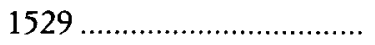 & 2.913 .000 \\
\hline 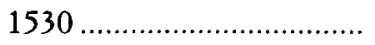 & 2.984 .296 \\
\hline 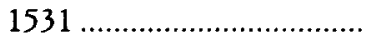 & 2.660 .997 \\
\hline 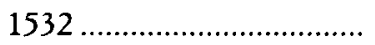 & 2.660 .997 \\
\hline 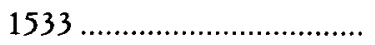 & 2.676 .425 \\
\hline 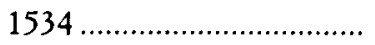 & 2.914 .197 \\
\hline $1535 \ldots \ldots \ldots \ldots \ldots \ldots \ldots \ldots \ldots \ldots \ldots \ldots \ldots \ldots \ldots \ldots \ldots$ & 3.173 .000 \\
\hline 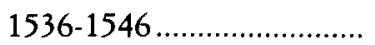 & 3.161 .300 \\
\hline $1547-1556 \ldots \ldots \ldots \ldots \ldots \ldots \ldots \ldots \ldots \ldots \ldots \ldots \ldots$ & 3.362 .000 \\
\hline
\end{tabular}

FuENTE: Hasta 1536, AGS, CMC, $10^{a}$ ép., legs. 62 y 831 . A partir de este año, Carande $\left(1990^{3}\right)$ y Ulloa $\left(1977^{2}\right)$.

una recaudación «demás» en relación con el encabezamiento; de otro modo, proporcionaban un dinero al margen de la recaudación propio de entidades colectivas que hoy identificaríamos con los Ayuntamientos. Las sobras, cierto es, sirvieron para esto en un aspecto redistributivo que a ellas correspondía. Pero no eran sólo una demasía recaudatoria para mantener gastos municipales. En el Madrid de Carlos V se produjo una durísima pugna entre el propio concejo y los miembros encabezados -mercaderes, tratantes, cambios...- por el control de estas sobras ${ }^{19}$. Es decir, que estas sobras no eran una propiedad inmediata a ningún poder público. Antes bien constituían una parte inherente al propio hecho de recaudar - y éste estaba en manos de los concejos hasta que luego el encabezamiento se desmembraba por menor- porque formaban una estructura propia y reco-

19 Alonso García (en prensa), pp. 173-183. 
nocida por todos. Incluido el rey, aquel que no era beneficiario económico -que sí político- por las fidelidades que despertaba. De otro modo, el beneficio de la ciudad constituía una parte inherente al hecho mismo de recaudar. La propia Corona no pretendía la identificación completa entre lo que recibía desde todas y cada una de las ciudades y la recaudación efectiva. He aquí una gran diferencia con el concepto clásico de impuesto. Pues parece difícil pensar en impuestos que se recaudaran para «beneficiar» al poseedor. En una discusión en el ayuntamiento madrileño, Bernardino de Mendoza se quejaba de «los pocos propios que esta villa tiene y $l o$ poco que gana con el encabeçamiento» ${ }^{20}$. El beneficio es algo reconocido y la propia Villa «tiene entendido la merçed y benefiçio grande que su magestad hará ha estos reynos en les dar e otorgar el dicho encabeçamiento general $[\ldots]{ }^{21}$. De ahí que incluso en un documento real se hable sin rubor alguno de «la cuenta de la ganancia del encaueçamiento» ${ }^{22}$. Bajo estas premisas no extraña, por ejemplo, que la propia Villa pague en ocasiones por conseguir el encabezamiento, esto es, pague por pagar ${ }^{23}$. En la propia provisión real que certificaba el encabezamiento de los años cuarenta se afirmaba que «nuestra voluntad [del rey] es que todos los vezinos e moradores de la dicha villa de Madrid e lugares de su tierra e los que a ella vinyeren a vender e contratar sus mercaderías gozen en quanto sea posible del benefiçio del dicho encabeçamiento [...]» ${ }^{24}$. Beneficio entendido como una rebaja de la presión fiscal sobre lo ordinario. Pero también entendido como el acceso a unos capitales justificados por la acción misma de recaudar.

\section{EL ENCABEZAMIENTO DE MADRID}

Todos los estudios sobre la fiscalidad castellana del siglo xv coinciden en un aspecto. El reinado de Carlos $\mathrm{V}$ constituyó un período de baja presión fiscal, en especial en cuanto a las rentas ordinarias se refiere. No es sino la famosa «petrificación» de las alcabalas de la que ya hablaba Carande.

${ }^{20}$ AVM, Secretaria, 3-65-9.

${ }^{21}$ AVM, Secretaria, 3-66-13.

22 AVM, Documentos Reales, 13 de noviembre de 1543.

23 «Acordaron que se tome [cambio] para embiar a la corte a Alonso de Villanueva para los dineros que a de pagar del sacar la çedula del encabeçamiento dyesisiete mill e tantos maravedís [...]». AVM, Actas municipales, 15 de julio de 152.1.

${ }^{24}$ AVM, Documentos Reales, 9 de diciembre de 1539. 
Este hecho, junto al propio contexto inflacionario, propició una reducción real de la presión fiscal en relación con lo ordinario ${ }^{25}$. Reducción que se vio compensada por un incremento desigual de los servicios ${ }^{26}$. Básicamente, este panorama continuó a lo largo de la primera mitad del siglo XVI. Entonces, ya desde 1562, podemos encontrar una tendencia al alza que explotará en 1575-1577, fecha en la que Felipe II intentó una ruptura del statu quo fiscal sin otro resultado que una vuelta atrás tras la enérgica oposición de las ciudades ${ }^{27}$. Es a partir de esta fecha cuando se iniciará un nuevo período cuya nota más sobresaliente será la grave presión fiscal sobre el mundo rural ${ }^{28}$. Esta situación se mantendrá hasta 1590, fecha de aprobación de los Millones. $Y$ fecha en la cual se inicia un nuevo período en la historia de la hacienda española.

La petrificación de lo ordinario en Madrid sólo aparece de modo claro con la llegada del encabezamiento general ${ }^{29}$. Para el período anterior a 1536 hay que matizar esta cuestión. Antes de 1521 se puede observar un repunte en las rentas tan breve como intenso. No sería otra cosa que el resultado del célebre arrendamiento de Barcelona ${ }^{30}$. La tendencia se invirtió en 1522, cuando se observa un brusco descenso de las rentas que benefició especialmente a la tierra. A partir de 1529, en cambio, hallamos otro ascenso impositivo. Sin embargo, sólo con la llegada del encabezamiento general Madrid supera el nivel impositivo nominal de los primeros años veinte. Claro que por el movimiento inflacionista de estos momentos hemos de considerar que tales datos no reflejan sino un descenso real de la presión fiscal (siempre en relación con lo ordinario). Además, hay que matizar la cuestión del crecimiento del encabezamiento de 1547. Antes de este año existe una doble administración dentro del propio partido de Madrid. El partido fiscal de Madrid, al menos en cuanto a lo ordinario se refiere, estaba compuesto por la Villa de Madrid con su tierra junto

${ }^{25} \mathrm{La}$ evolución de los rendimientos fiscales de conjunto a lo largo de todo el Antiguo Régimen pueden seguirse en Gelabert (1999); cfr. Yun Casalilla y Comín (2001). El trabajo más completo en cuanto a datos es Zabala Aguirre (2000). Finalmente, el trabajo metodológicamente más logrado en cuanto a la reconstrucción de la presión fiscal es Bilbao Bilbao (1987). Estos trabajos se ven perfectamente complementados por Fortea (1986), (1992). La evolución de la carga fiscal madrileña a lo largo de la Edad Moderna, en López García (1998), pp. 58 y 295 ss.

${ }^{26}$ Carretero Zamora (1998).

${ }^{27}$ Fortea (1990).

${ }^{28}$ Vid. Fortea (1986).

29 Vid. gráfico 1.

${ }^{30}$ Pérez (19997), pp. 129-135, y Carretero Zamora (1999). 
a Zorita, parte de Guadalajara y parte de Toledo ${ }^{31}$. Dentro de la demarcación fiscal, encontramos dos estructuras principales de recaudación antes de 1547: por un lado, el encabezamiento de la Villa de Madrid en el que entraban tanto sus alcabalas y tercias como las tercias de la tierra junto a las tercias de Parla, Polvoranca y Mejorada ${ }^{32}$; por otra parte, iba el encabezamiento de las alcabalas de distintos pueblos de la tierra. Ambas estructuras tenían receptores o recaudadores distintos antes de $1547^{33}$. Es decir, que antes de este año encontramos una bifurcación de las cifras que dificulta la reconstrucción seriada. Será sólo a partir de este año cuando encontremos una unificación administrativa en la gestión del encabezamiento de partido. Proceso que contó con un precedente claro con el encabezamiento de 1536, cuando ya la Villa se encabezará por sus lugares sin asumir el pago directo ${ }^{34}$. Más significativo incluso, resulta la ratio entre rentas encabezadas y rentas arrendadas entre 1520 y $1534^{35}$. La política de encabezamiento irá ganando terreno al arrendamiento. Si ya Madrid (ciudad) andaba encabezada desde fines del siglo $\mathrm{xv}^{36}$, serán ahora los pueblos de la tierra quienes progresivamente vayan entrando en un sistema que garantizaba beneficios mancomunados.

Los datos del cuadro 2 denotan a la perfección la preferencia por el encabezamiento de distintos pueblos del alfoz. Preferencia que se agudizará

\section{GRÁFICO 1}

Evolución de las rentas de Madrid (1520-1556)

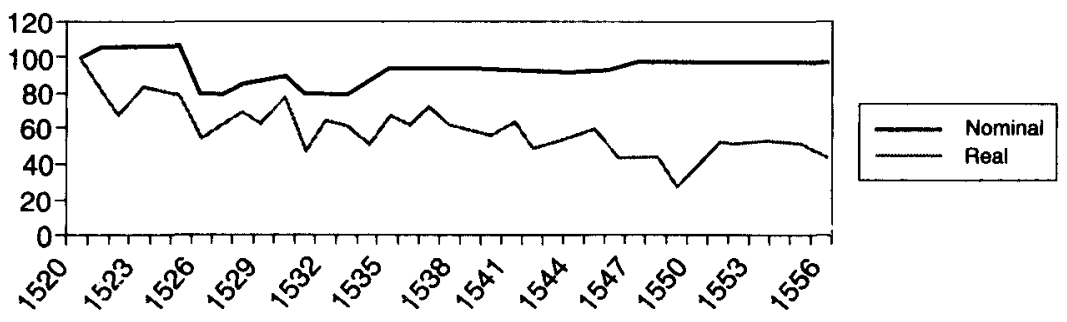

FUENTE: Cuadro 1. La evolución en términos reales se ha calculado según la serie de precios de Reher y Balleteros (1993), p. 131.

\footnotetext{
${ }^{31}$ Zabala Aguirre (2000), p. 43.

32 AVM, Secretaria, 3-66-26.

${ }^{33}$ Alonso García (en prensa).

${ }^{34}$ AVM, Documentos reales, 9 de diciembre de 1539.

${ }_{35} \mathrm{Vid}$. cuadro 2.

${ }^{36}$ Losa Contreras (1999), pp. 428 ss.
} 


\section{CUADRO 2}

Evolución de lo encabezado y arrendado del partido de Madrid (1520-1534) (en maravedis)

\begin{tabular}{|c|c|c|}
\hline Año & Encabezado & Arrendado \\
\hline 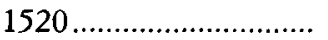 & 654.204 & 1.186 .377 \\
\hline $1521 \ldots \ldots \ldots \ldots \ldots \ldots$ & 675.249 & 1.346 .377 \\
\hline $1522 \ldots .$. & 766.781 & 1.246 .477 \\
\hline $1523 \ldots$ & 766.781 & 1.241 .000 \\
\hline $1524 \ldots \ldots \ldots \ldots \ldots$ & 794.421 & 1.241 .000 \\
\hline $1525 \ldots \ldots \ldots \ldots \ldots \ldots$ & 823.417 & 1.241 .000 \\
\hline 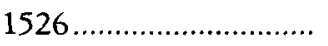 & 823.417 & 323.750 \\
\hline $1527 \ldots \ldots \ldots \ldots \ldots \ldots \ldots$ & 841.017 & 323.750 \\
\hline $1528 \ldots \ldots \ldots \ldots \ldots \ldots \ldots$ & 1.080 .617 & 323.750 \\
\hline 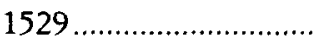 & 1.110 .397 & 323.750 \\
\hline $1530 \ldots \ldots \ldots \ldots \ldots \ldots \ldots \ldots \ldots \ldots \ldots \ldots$ & 1.181 .598 & 323.750 \\
\hline $1531 \ldots \ldots \ldots \ldots \ldots \ldots \ldots$ & 1.182 .049 & \\
\hline 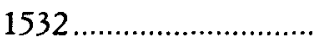 & 1.182 .049 & \\
\hline $1533 \ldots \ldots \ldots \ldots \ldots \ldots \ldots \ldots \ldots \ldots \ldots$ & 1.197 .477 & \\
\hline $1534 \ldots \ldots \ldots \ldots \ldots \ldots \ldots \ldots$ & 1.435 .149 & \\
\hline
\end{tabular}

FUENTE: AGS, CMC, 1. ${ }^{\circ}$ ép., leg. 62. No incluye el encabezamiento de Madrid-ciudad.

\section{GRÁFICO 2}

Evolución de lo encabezado y arrendado de Madrid (1520-1534)

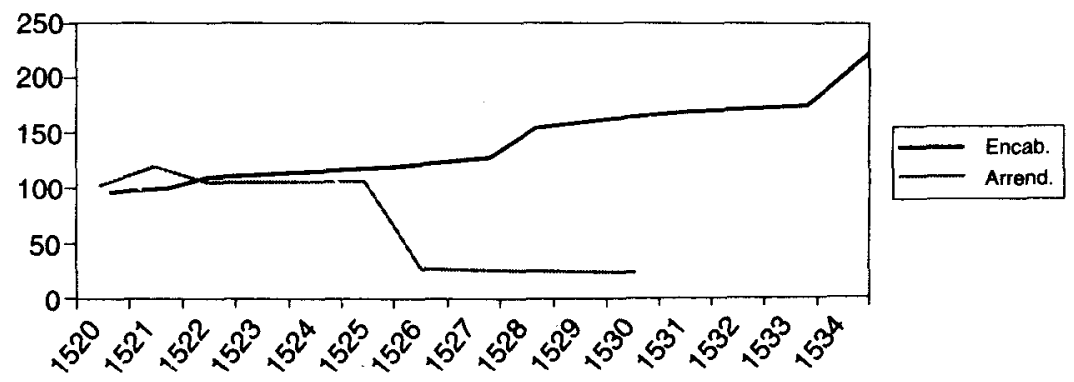

Fuente: AGS, CMC, 1.a ép., leg. 62. 
a finales de la década de los veinte. De hecho, se puede afirmar que sólo el recurso al encabezamiento - variable y ascendente cada año- permitió un mantenimiento de los niveles de rentas hasta 1536. El arrendamiento, excepción hecha de los primeros años veinte, entró en una espiral descendente muy evidente. Es más, ya no encontramos arrendamientos directos entre pueblos y rey en 1531. Es así como paulatinamente se fue formando el encabezamiento general y el propio partido de Madrid como entidad fiscal única y unívoca. ¿Por qué la preferencia de los encabezamientos? De nuevo hemos de remitirnos al concepto de beneficio en un contexto político en el que Carlos V necesitaba asegurar la gobernabilidad del territorio para superar la crisis con la que comenzaba su reinado. Es, en definitiva, la relativa victoria de las Comunidades ${ }^{37}$.

El cargo más importante del encabezamiento de partido procedía del propio encabezamiento de la ciudad ${ }^{38}$. La característica más reseñable del encabezamiento madrileño es su casi total estabilidad. El encabezamiento madrileño se mantenía en 1.478 .948 maravedís desde antes de la llegada de Carlos V al trono ${ }^{39}$. Y este precio fue conservado hasta 1532. Sólo con la llegada del encabezamiento general comenzó el aumento de las rentas que nunca se convertiría en un incremento real de la presión fiscal por rentas ordinarias. Finalmente, recordemos que el incremento de 1547-1556 se debió fundamentalmente a la completa identificación entre encabezamiento de partido y encabezamiento de la Villa. Se completaba así un proceso de acumulación de rentas, lo cual por sí mismo propició cambios en el poder fiscal ${ }^{40}$. Por esta estabilidad del encabezamiento madrileño, los cambios operados antes de la llegada del encabezamiento general repercutían generalmente en la tierra. Madrid, como persona, estaba a salvo de los vaivenes fiscales anteriores a 1536.

\section{LA FORTUNA DE MADRID}

El pacto fiscal entre Corona y Reino no acababa con la gestión directa de los tributos por parte de las ciudades. También había un componente económico de trascendental importancia, tanto para entender las relaciones entre rey y reino como el desarrollo del poder a nivel local. Ahora bien,

\footnotetext{
${ }^{37}$ Vid. Hendricks (1976) y Halizcer (1987).

38 Vid. cuadro 3.

39 Losa Contrera (1999), p. 430.

40 Bonney (1996).
} 
hay que entender que existían distintos tipos de sobras. Por un lado, contamos con unas sobras por mayor, las cuales servían para sostener el aparato administrativo de la Diputación en Cortes. Cantidades que hubieron de ser importantes. ¿Sólo esto? La Diputación únicamente podía acaparar todo el montante de las sobras por mayor cuando éstas fueran menores a 6.000.000 de maravedís. En caso contrario habrían de repartirse de modo proporcional entre las distintas ciudades y pueblos ${ }^{41}$. $\mathrm{Y}$, efectivamente, así parece que ocurría según se puede apreciar a partir del ejemplo madrileño. En este caso, creemos, las sobras no eran una demasía recaudatoria, sino una rebaja sobre el precio del encabezamiento:

«Yo Alonso Núñez Ruvio, escribano de sus magestades e del conçejo de la villa de Auñón, doy fe y verdadero testimonio a todos los señores que la presente vieren como el año de myll e quynientos çincuenta y dos años se traxo a esta villa una provysión de su magestad por la qual su magestad hacia merçed a çiertas villas desta provynçia de Çorita de çiertos maravedis que dezia aver avido a ganançia en el encabeçamiento general de las alcavalas $[\ldots] \gg{ }^{42}$.

No estamos en disposición de seriar estas sobras por mayor. Pero a buen seguro que hubieron de ser muy importantes. Ya en el primer encabezamiento general se hacía baja de «veynte mill ducados de oro cada año de los quales hazemos merçed al dicho Reyno con que ellos lo tomasen

\section{CUADRO 3}

Evolución del encabezamiento de Madrid-ciudad (1517-1556) (en maravedis)

\begin{tabular}{|c|c|}
\hline$A \overline{n o}$ & Encabezamiento nominal \\
\hline $1517-1532$. & 1.478 .948 \\
\hline $1533-1544 \ldots \ldots$. & 1.718 .948 \\
\hline 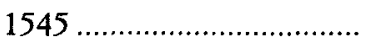 & 2.034 .763 \\
\hline 1546 & 2.123 .915 \\
\hline 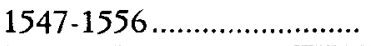 & 3.362 .000 \\
\hline
\end{tabular}

FUENTE: Espejo (1927); AVM, Secretaría, 3-64-26, 3-64-27, 3-64-24, 3-64-18, 3-65-2, 3-64-34, 3-64-38, 3-64-44, 3-64-49; AGS, $E H$, leg. 121, núm. 5; EMR, legs. 157, 232 y 258; CMC, 1. "ép., leg. 831 , núm. 2.

${ }^{41}$ Tomás y Valiente (1982), pp. 116-117.

42 AGS, C(onsejo) y J(untas) de H(acienda), leg. 26, núm. 299. 
todo a su cargo y asegurasen y se obligasen de pagar el dicho preçio [del encabezamiento general $]_{\gg}{ }^{43}$. Es evidente que no se producía una disminución de la presión fiscal, sino un transvase de dinero entre dos entidades de poder. Un verdadero pacto. De ahí que también el Reino mostrase su agradecimiento:

«Por rreconpensar en algo la merçed que se hazía a todo el Reyno en el dicho encabeçamiento y por lo que sus magestades avían llevado e gozado de las rentas del rreyno el dicho año de quinientos y treynta y cuatro obligava a sus çiudades e a las otras çiudades e villas del rreyno en cuyo nonbre otorgaron el dicho encabeçamiento general [...] que darían e pagarían a sus magestades o a quien por sus magestades lo oviere de aver en cada año de los diez años del encabeçamiento general el preçio en quantía que conforme al dicho encabeçamiento y escritura sobrello fecha e otorgada e a de dar e pagar e otros çinco mill ducados más en cada uno de los dichos diez años $[\ldots] \gg{ }^{44}$.

Desde aquí se puede observar cómo en el encabezamiento entraban una serie de contraprestaciones recíprocas. En 1536 aumenta el precio del encabezamiento de Madrid. En la negociación que concluiría con la entrada de Madrid en el encabezamiento general, el contador Cristóbal Suárez aconsejaba al concejo de Madrid que aprobase sin recelo alguno la puja de los 5.000 ducados «porque con aquello queda grand provecho e ynterese al Reyno en las rentas más de lo que se pensaua quando se començó a entender $[\ldots]{ }_{{ }^{45}}$. El Reino, por su parte, hacía suyos otros 5.000 ducados. Estos 10.000 ducados constituían la diferencia entre el rendimiento de las alcabalas de 1534 y 1536. En 1536, por tanto, se recaudan 10.000 ducados más que dos años antes que se repartirían entre Corona y Reino.' Y esto sin contar los 20.000 ducados que se rebajaban a las ciudades.

Entonces, como ya hemos indicado, las bajas del encabezamiento general se aplicaban particularmente a las ciudades. En 1540 Madrid paga de encabezamiento 2.034 .763 , «y es menos que otros años porque su magestad descargó e quitó este año quatro por çiento del preçio del encabeçamiento» ${ }^{46}$. Este 4 por 100 equivalía a 89.152 maravedís «que an de llevar e gozar aquellas personas y conçejos que de justiçia an de gozar de la

${ }^{43}$ AVM, Documentos Reales, 8 de septiembre de 1536.

44 AGS, EMR, leg. 245.

45 AVM, Secretaria, 3-457-6.

46 AVM, Secretaria, 3-64.49. 
ganançia o para la pérdida que oviere en el encabeçamiento desa dicha villa y su tierra y partido» ${ }^{47}$. También a los pueblos de la tierra se les aplicará este descuento ${ }^{48}$. En principio, estos maravedís de baja se aplicarían a 1540 y 1541 . Sin embargo, en 1545 el receptor del partido de Madrid recibe estos 4 por 100 del recaudador de las tercias del partido de Zorita. Como no podía ser de otro modo, el objetivo era «pagar los quatro por çiento que la dicha villa de Madrid e su tierra ovieron de aver el dicho año de 545 de la dicha ganançia que ovo en el encabeçamiento general el dicho año» ${ }^{49}$. En 1552 Madrid recibe 201.720 maravedís por este mismo concepto ${ }^{50}$. En 1555 la rebaja alcanzaba, nada más y nada menos, que al 3 por 100 de la ganancia total de todo reino en este año ${ }^{51}$. Las bajas de encabezamiento por mayor no parecen un elemento al margen de la Monarquía; tampoco hay que considerar que nos hallamos ante una desviación por recaudación. Entendemos que este dinero constituía una parte inherente y propia de una constitución fiscal que beneficiaba al rey y oligarquías. Constitución cuyo fundamento último hay que rastrear en la vinculación entre renta y beneficio. Así que, en 1543:

«No ovo baxa de los quatro por çiento [para Madrid] porque ovo mal rrecaudo en una rrenta que se arrendó por los diputados passados [...] y assí se hizo en que el rreyno ganó dineros hartos. Vino a hazerse el rremate de las rrentas passadas ya çinco o seis meses del dicho año de quarenta $\mathrm{y}$ tres, y porque heran ya despachadas todas las rreçeptorías del dicho rreyno no se pudo hazer baxa de los quatro por çiento el dicho año sobraron de ganançia de encabeçamiento seys qüentos y çincuenta mill maravedís y seyçientas y çincuenta y dos fanegas. Destos seys qüentos el rreino dio los quatro dellos para en cuenta del seruiçio con que este año de quinientos y quarenta y quatro se siruió a su magestad, los dos quentos y çinquenta myll quedan para el cuerpo de la hazienda entre el rrey y rreyno» ${ }^{52}$.

Por tanto, en 1543, parte del servicio se pagó de estas sobras por mayor, por lo que del pago por tributo se pasaba al pago por auxilium. Este hecho, desde un plano jurídico, no era cuestión baladí. No significaba lo mismo el pago por servicio - dependiente en último término de la voluntad del otorgante- que por tributo. En 1544 se volvía al modelo

${ }^{47}$ AGS, C(ontaduría) M(ayor) de C(uentas), 1. ${ }^{a}$ ép(oca), leg. 831, núm. 2.

48 Alonso García (2000), pp. 156-161.

49 AGS, CMC, 1. ép., leg. 831, núm. 2.

50 AVM, Actas municipales, 26 de septiembre de 1552.

${ }^{51}$ AGS, CMC, 1. ‘ ép., leg. 831, núm. 2.

${ }^{52}$ AVM, Secretaria, 2-394-9. 
de rebaja del 4 por 100 a la ciudad. Porcentajes que había de pagar el receptor del rey a la propia Villa ${ }^{53}$. Es decir, la relación fiscal entre el rey y Madrid no era unidireccional; el receptor del rey, por el juego mismo de ganancias por mayor, podía soltar dinero a favor de la ciudad. Y de este modo, con el encabezamiento, presenciamos unas relaciones mucho más recíprocas que en sistemas tributarios exclusivamente impositivos.

Después de estas sobras por mayor, Madrid contaba con el beneficio de unas sobras inherentes al propio hecho de recaudar. Son las conocidas sobras por menor. Sobras que constituían la diferencia entre lo pagado por el encabezamiento y lo efectivamente recaudado, esto es, entre lo recaudado por menor y lo pagado por mayor. $A$ priori, estas cantidades serían sencillas de cuantificar con la existencia de instituciones y cargos que centralizaran toda la gestión, de modo impersonal. Para el caso madrileño, lo más parecido a esto sería el receptor de la Villa. Metodológicamente, entonces, tendríamos que comparar las cuentas del encabezamiento con el cargo total que presentara el receptor ${ }^{54}$. Sin embargo, existe un grave problema que desvirtúa tal procedimiento: el receptor no presenta la cuenta de una institución o de un cargo público, sino que tiene que declarar lo que ha recibido y ha pagado como persona. Es decir, que pueden entrar conceptos distintos al ingreso y al gasto. Todo esto significa que sus cuentas pueden no ser totales. $Y$, a la inversa, también se pueden encontrar otras personas - receptor del rey, arrendadores, concejo de la tierra o cambiadores- que recibiesen y pagasen dentro del propio encabezamiento.

La interpretación de los datos del cuadro 4 es distinta según si la diferencia es positiva o negativa; si la diferencia es positiva, indica que el receptor de la Villa ha recaudado por encima del encabezamiento. Esta cantidad puede coincidir o no con la recaudación total de la Villa, pero al menos sabemos que existió un superávit respecto al encabezamiento. En el lado inverso, cuando la diferencia es negativa, literalmente significa que el receptor de la Villa ha recaudado menos de lo pagado por el encabezamiento. De hecho, los alcances a favor de la Villa continuaron a partir de 1547 (pero no en relación con el encabezamiento): en 1552, cuando la Villa parece perder dinero, el receptor tuvo unas ganancias de 259.037 maravedís que habría de pagar a Madrid ${ }^{55}$. En 1550 , en cambio, la Villa adeuda a su propio receptor $78.570,5$ maravedís ${ }^{56}$. Y es que, por razones

\footnotetext{
53 AVM, Secretaria, 3-65-23.

54 Vid. cuadro 4.

55 AVM, Secretaria, 3-65-29.

56 AVM, Secretaría, 3-66-10.
} 


\section{CUADRO 4}

Diferencia del cargo del receptor de la Villa con el encabezamiento (1521-1555) (en maravedis)

\begin{tabular}{|c|c|c|c|}
\hline Año & $\begin{array}{l}\text { Cargo total } \\
\text { del receptor } \\
\text { de la villa }\end{array}$ & $\begin{array}{c}\text { Diferencia } \\
\text { con el } \\
\text { encabezamiento }\end{array}$ & $\begin{array}{c}\text { Diferencia porcentual } \\
\text { con el } \\
\text { encabezamiento }\end{array}$ \\
\hline $1521 \ldots \ldots \ldots \ldots \ldots \ldots$ & $1.623 .624,0$ & $+144.676,0$ & $+9,78$ \\
\hline 1523 & & $+1.134 .109,0$ & $+76,68$ \\
\hline \multicolumn{4}{|l|}{$1524 \ldots \ldots \ldots \ldots \ldots \ldots$} \\
\hline 1525. & $2.085 .853,5$ & $+606.905,0$ & $+41,03$ \\
\hline 1526 & $1.839 .796,0$ & $+360.848,0$ & $+24,39$ \\
\hline ............... & $1.780 .599,0$ & $+301.651,0$ & $+20,39$ \\
\hline \multicolumn{4}{|l|}{1528} \\
\hline $1529 \ldots \ldots \ldots \ldots \ldots$ & $3.543 .985,0$ & $+2.065 .037,0$ & $+139,62$ \\
\hline $1530 \ldots \ldots \ldots \ldots \ldots \ldots$ & $1.849 .016,0$ & $+370.068,0$ & $+25,02$ \\
\hline $1531 \ldots \ldots \ldots \ldots \ldots \ldots$ & $1.976 .002,5$ & $+497.054,5$ & $+33,6$ \\
\hline \multicolumn{4}{|l|}{1532.} \\
\hline \multicolumn{4}{|l|}{$1533 \ldots \ldots \ldots \ldots \ldots \ldots$} \\
\hline $1534 \ldots \ldots \ldots \ldots \ldots \ldots$ & $2.144 .316,0$ & $+425.368,0$ & $+24,74$ \\
\hline $1535 \ldots \ldots \ldots \ldots \ldots \ldots$ & $2.789 .150,5$ & $+1.070 .202,5$ & $+62,25$ \\
\hline $1536 \ldots \ldots \ldots \ldots \ldots$ & $2.029 .751,5$ & $+310.803,5$ & $+18,08$ \\
\hline $1537 \ldots \ldots \ldots \ldots \ldots \ldots$ & $1.916 .452,0$ & $+197.452,0$ & $+11,14$ \\
\hline $1538 \ldots \ldots \ldots \ldots \ldots$ & $1.849 .065,0$ & $+130.117,0$ & $+7,56$ \\
\hline $1539 \ldots \ldots \ldots \ldots \ldots$ & $2.642 .652,0$ & $+923.704,0$ & $+53,73$ \\
\hline $1540 \ldots \ldots \ldots \ldots \ldots \ldots$ & $3.844 .975,0$ & $+1.721 .060,0$ & $+81,03$ \\
\hline $1541 \ldots \ldots \ldots \ldots \ldots$ & $3.640 .179,0$ & $+1.516 .264,0$ & $+71,39$ \\
\hline $1542 \ldots \ldots \ldots \ldots \ldots \ldots$ & $2.016 .422,0$ & $-107.493,0$ & $-5,07$ \\
\hline $1543 \ldots \ldots \ldots \ldots \ldots \ldots$ & $2.703 .173,5$ & $+579.585,0$ & $+27,29$ \\
\hline $1544 \ldots \ldots \ldots \ldots \ldots \ldots$ & $1.895 .715,0$ & $-228.200,0$ & $-10,75$ \\
\hline $1545 \ldots \ldots \ldots \ldots \ldots \ldots \ldots$ & $2.728 .613,0$ & $+604.698,0$ & $+28,47$ \\
\hline $1546 \ldots \ldots \ldots \ldots \ldots \ldots$ & $3.293 .875,0$ & $+1.116 .996,0$ & $+51,31$ \\
\hline $1547 \ldots \ldots \ldots \ldots \ldots \ldots$ & $2.627 .997,0$ & $-734.003,0$ & $-21,84$ \\
\hline $1548 \ldots \ldots \ldots \ldots \ldots \ldots$ & $2.546 .754,0$ & $-815.246,0$ & $-24,25$ \\
\hline 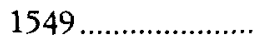 & $2.509 .638,0$ & $-852.362,0$ & $-25,36$ \\
\hline $1550 \ldots \ldots \ldots \ldots \ldots \ldots \ldots$ & $2.433 .441,5$ & $-928.558,0$ & $-27,62$ \\
\hline $1551 \ldots \ldots \ldots \ldots \ldots \ldots \ldots$ & $2.485 .352,0$ & $-876.648,0$ & $-26,08$ \\
\hline $1552 \ldots \ldots \ldots \ldots \ldots \ldots$ & $3.319 .103,0$ & $-42.897,0$ & $-1,28$ \\
\hline $1553 \ldots \ldots \ldots \ldots \ldots \ldots$ & $2.707 .816,0$ & $-654.184,0$ & $-19,46$ \\
\hline 1554 & $2.059 .228,0$ & $-1.302 .772,0$ & $-38,75$ \\
\hline $1555 \ldots \ldots \ldots \ldots \ldots \ldots \ldots$ & $2.067 .853,0$ & $-1.239 .147,0$ & $-38,5$ \\
\hline
\end{tabular}

FUENTE: Alvar (1989), p. 259; AVM, Secretaría, 3-64-24; 3-65-2; 3-64-34; 3-64-38; $3-64-44 ; 3-65-16 ; 3-65-13 ; 3-64-49 ; 3-65-19 ; 3-65-21 ; 3-66-2 ; 3-65-25 ; 3-66-5 ; 3-65-29$. 
desconocidas, el receptor de la Villa de la década de los cincuenta paga bastante menos por el encabezamiento de lo que realmente le correspon$\mathrm{de}^{57}$, lo cual no significa que el encabezamiento no se cubriese ${ }^{58}$. Simplemente, el origen de ingresos y gastos podía tener un origen variado debido a la existencia de distintas fórmulas de financiación.

El concepto beneficio como clave de un sistema. En este momento nos proponemos la comparación de lo cargado y descargado por el receptor de la Villa. Esto implica, para el descargo, que las cifras del gasto son superiores al encabezamiento (partida principal del gasto según la percepción de la Villa) porque aquí entraban las libranzas que habían de ser satisfechas. Esto significa que el resultado es el líquido que queda o falta en relación con el receptor, y que no tiene por qué coincidir con déficit o superávit. En este sentido, existen muy pocos años en los que el receptor pagaba más de lo que ingresaba. Es decir, descontando el encabezamiento y los propios gastos municipales, la tendencia general será al alcance a favor de la Villa (es decir, que el receptor debía pagar la diferencia entre lo ingresado y lo gastado). Este hecho, en nuestra opinión, es una señal definitiva de la buena coyuntura fiscal. A fin de cuentas, unos rendimientos fiscales que tampoco eran especialmente onerosos - nos referimos al ordinario, nunca al extraordinario- daban para pagar al rey, satisfacer los distintos gastos municipales y, además, otorgar cierta liquidez. Parece más que evidente el interés de Madrid en la continuidad del sistema de encabezamientos.

Observemos con más detalle estas diferencias. En 1514 el alcance del receptor ascendió a 22.699 maravedís ${ }^{59}$. Los alcances de 1515 y 1516 fueron, respectivamente, de 15.000 y 47.890 maravedís ${ }^{60}$. Gaspar Dávila, receptor de la Villa, fue alcanzado en 1520 por 14.536 maravedís, mientras que en el ejercicio de 1521 y 1522 sus beneficios ascendieron a $79.992^{61}$. No es de extrañar, por tanto, la existencia de testimonios que nos acercan a la existencia de sobras para estos años: «[...] Yo soy ynformado que esa dicha villa tiene por encabeçamiento las rentas de las nuestras alcavalas y terçias, e que gana en el dicho encabeçamiento mucha cantidad de maravedis $[\ldots]_{\gg}{ }^{62}$. En 1523, en cambio, es la Villa quien adeuda al receptor

\footnotetext{
57 Vid. Alvar (1989), p. 259.

58 AGS, CMC, 1. ${ }^{a}$ ép., leg. 831, núm. 2.

59 AVM, Secretaria, 3-80-1.

60 AVM, Secretaría, 3-66-26.

61 AVM, Secretaría, 3-64-24.

${ }^{62}$ AVM, Secretaria, 3-66-26.
} 
3.102 maravedís ${ }^{63}$. La Villa continuó con un serio problema deficitario -en relación, insistimos, con su propio receptor y no en relación con lo pagado al rey- hasta 1526. La Villa perdió en estos años 146.284 maravedís ${ }^{64}$.

En 1527 vuelve a invertirse la tendencia y es la Villa quien debe recibir líquido por parte del receptor. En concreto, para 1527 la cantidad asciende a 183.369 maravedís ${ }^{65}$. Es más, según las cuentas de un juez de comisión, estas ganancias ascendieron para 1529 y 1530 a 1.085 .429 maravedís ${ }^{66}$. En 1531 la Villa "sólo" ganaba 304.769,5 maravedís ${ }^{67}$. Para 1537 estas sobras eran de $128.061{ }^{68}$ mientras que en 1538 se redujeron las ganancias a 29.118 maravedís «que queda para salarios y costas» ${ }^{69}$. Entre 1538 y 1544 los alcances favorables a la Villa ascendieron a 3.344 .783 maravedís ${ }^{70}$. Sólo en 1541 la Villa obtuvo una ganancia de 1.604 .903 maravedís ${ }^{71}$. Las ganancias de 1545 fueron de $82.284^{72}$ mientras que en 1546 la cuantía era de 181.164 maravedís $^{73}$. Y es que las cantidades manejadas por los receptores de la Villa no tienen desperdicio: en este año de 1516 el receptor de la Villa recaudó 165.442 maravedís más que el propio receptor del monarca ${ }^{74}$.

Con la renovación del encabezamiento general de 1547 continuaron las ganancias. En este año, Pedro de la Carrera - receptor de la Villahubo de pagar 171.064 maravedís de diferencia entre el cargo y data. En 1549 el alcance era de 201.587 maravedís $^{75}$. Sólo en 1550 se había producido una pérdida - la primera desde los años veinte- de 78.570 maravedís ${ }^{76}$. Globalmente, en cambio, continuó la misma tendencia. Sólo entre 1550 y 1555 la Villa salió favorecida respecto a su receptor en 1.245.708,5 maravedís ${ }^{77}$. La percepción de ganancias vinculadas a la llegada de la Corte

\footnotetext{
${ }^{63}$ AVM, Secretaria, 3-64-19.

${ }^{64}$ AVM, Secretaria, 3-64-18.

${ }^{65}$ AVM, Secretaría, 3-64-34

${ }_{66}$ AVM, Secretaría, 3-64-38.

${ }^{67}$ Ibidem.

${ }^{68}$ AVM, Secretaria, 3-64-4.

${ }^{69}$ AVM, Secretaria, 3-65-13.

${ }^{70}$ AVM, Secretarí, 3-64-44

${ }^{71}$ AVM, Secretaría, 3-65-19.

72 AVM, Secretaria, 3-66-2.

${ }^{73}$ AVM, Secretaria, 3-65-25.

${ }^{74}$ Ibidem.

${ }^{75}$ AVM, Secretaria, 3-66-9.

${ }^{76}$ AVM, Secretaria, 3-66-10.

${ }^{77}$ AGS, E(xpedientes) de H(acienda), leg. 121, núm. 3.
} 
estaba muy clara: en 1552 se afirma tajantemente cómo «las sobras se an ganado con la venyda de la corte» ${ }^{78}$. Las ganancias - si bien menorestambién eran propias de momentos en los que la Corte no estuviera en Madrid; en 1558, en unas cuentas parciales, aparece un alcance de $\mathbf{4 3 9 . 9 7 2}$ maravedís ${ }^{79}$. Con la llegada de la Corte se disparaban las cifras de ingresos y gastos, lo cual suponía una mayor capitalización de la ciudad junto a mayores inversiones o políticas redistributivas ${ }^{80}$. En cambio, el precio del encabezamiento no variaba. La llegada de la Corte a la ciudad interesaba a diferentes grupos. Y entre los puntos de interés estaba la propia fiscalidad. Poder y fiscalidad, todo ligado, envolvían la llegada de la Corte a Madrid.

\section{CONCLUSIONES}

¿A qué nos lleva todos los datos que venimos exponiendo? ¿Estamos introduciendo un elemento nuevo susceptible de hacer variar la visión que poseemos sobre la hacienda de Castilla durante el siglo xvi? Porque, en la actualidad, conocemos los rendimientos nominales de los distintos encabezamientos, esto es, lo que en teoría recibía el Monarca por este concepto. También, en parte, conocemos lo efectivamente pagado al Monarca. Pero aquí no acababa el problema; porque todo ello no constituye sino la percepción que se tenía desde la propia Corona. Pero la Corona era un actor más, el más importante sin duda, pero nunca el único. En el reinado de Carlos V, con un contexto económico y demográfico realmente extraordinario, la existencia de estas sobras no supuso un esfuerzo inaguantable para el grueso de los contribuyentes. Es más, creemos que incluso introduciendo el concepto beneficio contamos con una evolución a la baja en la presión fiscal real durante el reinado del emperador en relación con las rentas ordinarias. Haría falta un estudio más exhaustivo sobre esta cuestión. Cuestión relacionada con el gasto, entendido éste a partir de criterios de redistribución. Porque si por parte del rey, con el objetivo de sufragar las distintas guerras, se produjo una descapitalización importante de Castilla ${ }^{81}$, no es menos cierto que precisamente la gestión de lo ordinario por parte de las ciudades proporcionaba unos ingresos que servían de dinamizador económico. Obras, abastecimientos o representaciones teatrales

\footnotetext{
${ }^{78}$ AVM, Actas municipales, 29 de abril de 1552.

79 AVM, Secretaria, 3-66-15.

80 Alonso García (en prensa), pp. 109-137.

${ }^{81}$ Thompson (2000).
} 
podían ser el objetivo último de estas sobras. $\mathrm{O}$, incluso, parte del servicio otorgado en las Cortes. Así se beneficiaba a distintos grupos desde el propio poder local. Poder local que a su vez se veía reforzado con este hecho. El rey contaba con el dinero necesario - según períodos-; pero nunca con todo lo que se recaudaba. A cambio, tenía asegurada la fidelidad y gobernabilidad de un territorio de enormes recursos. Y la población en general -hay que insistir en la importancia del contexto económicoveía satisfechas ciertas expectativas desde el gasto municipal. Acaso este hecho ayude a entender el incremento del endeudamiento tanto del rey como de las ciudades ${ }^{82}$.

El encabezamiento constituía el sistema que posibilitaba todo el juego. Encabezamiento que sustituía al arrendamiento como círculo de retroalimentación financiera. Anteriormente, el sistema de arrendamientos directos con el rey coadyuvaba al negocio de unos financieros que luego volvían a reinvertir el dinero en la propia monarquía, vía nuevos arrendamientos o vía asientos, entre otros, para el pago de las guardas ${ }^{83}$. Aquí mismo ya encontramos el fundamento último de la Hacienda castellana del Antiguo Régimen. Este sistema cambió más en las formas que en el fondo con la llegada del encabezamiento. Porque tanto con arrendamientos como con encabezamientos, existía una visión «empresarial» de la fiscalidad por la que los beneficios logrados por una parte volvían - en parte- a manos del rey a partir de lo extraordinario y el recurso a la deuda. Para cuadrar el círculo - si se nos permite-, tendríamos que ver las relaciones entre estas oligarquías y la gran banca internacional. Consideramos que la clave de esta relación se encuentra en la propia banca castellana, integrada también por aquellos antiguos arrendadores.

¿Problema? Creemos que nos encontramos ante un sistema formado y desarrollado en un contexto económico muy determinado. Este sistema fiscal necesitaba de una amplia capitalización, un intenso intercambio monetario -incluido el gasto-, y una gran absorción de capitales que no se dedicaban a la inversión productiva. El negocio financiero - juros, censos...- era más lucrativo. Además, tanto por la cantidad de masa monetaria que se precisaba como por la propia velocidad de los intercambios financieros, nos hallamos ante un sistema que incidía muy directamente en la procesa inflación. Y lo más grave es que entonces no existían los mecanismos de corrección necesarios para equilibrar el sistema. Por todo

${ }^{82}$ Vid. Pardo (1984). Sobre el endeudamiento municipal en la Edad Moderna, Martínez Ruiz (1992).

${ }^{33}$ Alonso García (1999). 
ello, el sistema sólo nos parece viable cuando el contexto económico «acompañase».

La creación de un sistema de beneficios ligados al encabezamiento no comenzó con Carlos V. Desde 1496 contamos con encabezamientos que comienzan a convivir con el sistema de arrendamientos ${ }^{84}$. La guerra de las Comunidades constituyó el elemento que aceleró el proceso. Tal movimiento demostraba a Carlos que no podía gobernar la Hacienda sin el concurso y beneplácito de otros actores a los cuales también se les debía hacer partícipes del sistema. El problema aparecería cuando la Corona, acuciada por sus propias necesidades financieras, intentara poner su mano sobre las sobras. Estamos pensando ya en el siglo xvII, cuando las alcabalas pasen a un segundo plano en relación con los millones. También los millones conllevaban unas ganancias a favor de las oligarquías urbanas. Atacar este sistema, desigual e injusto a todas luces, constituía un problema de enorme envergadura en tanto resquebrajaba muy seriamente todo el sistema de poderes establecido. Porque arrojarse sobre las ganancias de las oligarquías no era otra cosa que atacar a su propio poder. He aquí, pensamos, otro límite al poder regio por parte de las oligarquías.

En este sentido, Madrid es un claro ejemplo de cómo se constituyó todo el sistema. Sistema que tenía unas normas que ambas partes debían seguir. De ahí que nos encontremos ante una verdadera constitución fiscal compuesta por un reparto no equitativo de las contribuciones. El sistema de sobras fue básico para la financiación del Madrid posterior a 1561. Las sobras de Madrid se disparaban en tiempos de estancia cortesana. Esto es muy evidente para los años posteriores a 1561. En 1569, por ejemplo, el superávit de Madrid respecto al encabezamiento era de 6.993.049 ${ }^{85}$. Los gastos aumentaban con la llegada de la Corte. Pero también se disparaban los ingresos. Y esto conllevaba ganancias que fundamentalmente redundaban en un mayor gasto dirigido desde el ayuntamiento. A esto hay que añadir que la mayor recaudación que conllevaba la estancia de la Corte no recaía sobre los vecinos. Recaía básicamente en la tierra y, fundamentalmente, sobre los mercaderes que acompañaban a la Corte. De ahí que desde 1561 se disparen el número de vecindades otorgadas a distintos artesanos y comerciantes. Hacerse vecino de Madrid después de 1561 era un auténtico privilegio (fiscal). Recordemos que el crecimiento demográfico madrileño se hizo a partir de la emigración. Pero hemos de

\footnotetext{
${ }^{84}$ Ladero Quesada (1973), pp. 30-32.

${ }^{85}$ AVM, Contaduría, 3-446-2.
} 
tener presente que ya en tiempos anteriores nos encontramos las mismas estructuras que componen y explican las variaciones operadas tras la definitiva instalación de la Corte en Madrid. Todo ello se puede apreciar perfectamente desde la fiscalidad, convertida una vez más en un maravilloso balcón desde el cual pueden vislumbrarse enormes procesos de cambio histórico.

\section{BIBLIOGRAFIA}

AlONSO GaRCía, D. (1999): «La configuración de lo ordinario en el sistema fiscal de la Monarquía. Una o dos ideas», en Studia Historica. Historia Moderna, núm. 21, pp. 117-152.

- (2000): El fisco de la gracia. El encabezamiento de Madrid en tiempos de Carlos V, Madrid, UCM (memoria inédita de licenciatura).

- (2001): «Fechas, mitos y símbolos: repensar el Madrid del siglo XV», en Campo de Calatrava, núm. 3, pp. 183-195.

- (en prensa): Gabellae Concertatae. Madrid y la bacienda real de Castilla en tiempos de Carlos V.

Alvar, A. (1989): El nacimiento de una capital europea. Madrid entre 1561-1606, Madrid, Turner.

Asenjo González, M. (1997): «Encabezamientos de alcabalas en Segovia y su episcopalía (1495-1506). Innovaciones fiscales y reacción social», en En la España Medieval, núm. 20, pp. 251-280.

Boвbio, N. (1992²): «La gran dicotomía: público/privado», en Estado, gobierno $y$ sociedad. Por una teoria general de la política, México D. F., Fondo de Cultura Económica, pp. 11-38.

BONNEY, R. (1996): «Les revenus», en E. BONNEY (dir.), Systèmes économiques et finances publiques, Paris, PUF, pp. 429-514.

BrenNan, G., y BuChanAN, J. M. (1980): The power of tax. Analytical foundations of a fiscal constitution, Cambridge, Cambridge University Press.

Bulgarelli LuCKas, A. (1993): L'imposta diretta nel regno di Napoli in Età Moderna, Milano, Franco Angeli.

CARANDE, R. (1990 $\left.{ }^{3}\right)$ : Carlos V y sus banqueros. Tomo II. La Hacienda real de Castilla, Barcelona, Crítica.

CÁRCEles DE GEA, B. (2000): Fraude y desobediencia fiscal en la corona de Castilla, 1621-1700, Valladolid, Junta de Castilla y León.

Carretero Zamora, J. M. (1998): «Los servicios de las Cortes de Castilla», en "Tirar con pólvora del rey» o el dinero de todos (estudios de Hacienda y Fiscalidad en la España Moderna), monográfico de Cuademos de Historia Moderna, núm. 2, pp. 15-58.

- (1999): «Los arrendadores de la Hacienda de Castilla (1517-1525)», en Studia Historica. Historia Moderna, núm. 21, pp. 153-190.

ColuINS, J. B. (1988): Fiscal Limits of Absolutism. Direct taxation in SeventeenthCentury France, Berkeley, Los Ángeles-Londres, University of Berkeley. 
Dedieu, J. P., y Ruiz, J. I. (1994): «Tres momentos en la historia de la Real Hacienda», en Cuadernos de Historia Moderna, núm. 15, pp. 77-99.

EsPejo, C. (1998): El encabezamiento de Madrid por Alcabalas, de 1547 a 1556, Madrid.

Fernandez Albadalejo, P. (1992): Fragmentos de Monarquia. Trabajos de Historia politica, Madrid, Alianza Editorial.

ForTEA, J. I. (1986): Fiscalidad en Córdoba. Fisco, economía y sociedad: alcabalas y encabezamientos en tierra de Córdoba, Córdoba, Universidad de Córdoba.

- (1990): Monarquía y Cortes en la Corona de Castilla. Las ciudades ante la política fiscal de Felipe II, Salamanca, Cortes de Castilla y León.

- (1992): «Los encabezamientos de alcabalas andaluces en la Hacienda real de Castilla (1557-1595)», en Poder politico e instituciones en la España Moderna, Alicante, Instituto de Cultura «Juan-Gil Albert», pp. 15-58.

- (2001): «Las cortes de Castilla en los primeros años del reinado de Carlos V, 1518-1536», en E. BELENGUER CEBRIÁ (coord.), De la unión de coronas al Imperio de Carlos V, Madrid, SECCFC, pp. 411-443.

GeLABERT, J. E. (1997): La bolsa del rey. Rey, reino y fisco en Castilla (1598-1648), Barcelona, Crítica.

- (1999): «Castile, 1504-1808», en R. Bonney (edit.), The rise of the Fiscal State in Europe c. 1200-1815, Oxford, Oxford University Press, pp. 201-241.

Gómez Álvarez, U. (1996): Revisión bistórica de la presión fiscal castellana (siglos XVI-XVIII), Oviedo, Universidad de Oviedo.

Halizcer, S. (1987): Los comuneros de Castilla. La forja de una revolución, 1475-1521, Valladolid, Universidad de Valladolid.

Hendricks, C. D. (1976): Charles $V$ and the "Cortes» of Castile. Politics in Renaissance Spain, Cornell University (Tesis doctoral inédita).

HeRnÁndeZ, B. (2001): «Real Hacienda y fiscalidad de reinos. Las finanzas catalanas en el Imperio de Carlos V», en J. Martínez Millán (coord.), Carlos V y la quiebra del bumanismo politico (1530-1558), vol. IV, Madrid, SECCFC, pp. 473-493.

Hernández, M. (1995): A la sombra de la Corona. Poder local y oligarquía urbana (Madrid, 1606-1808), Madrid, Siglo XXI.

- (1999): «Oligarquías: ¿con qué poder?», en F. J. ArandA, Poderes intermedios, poderes interpuestos. Sociedad y oligarquías en la España Moderna, Cuenca, Universidad de Castilla-La Mancha, pp. 15-38.

Ladero Quesada, M. A. (1973): La Hacienda Real de Castilla en el siglo XV, La Laguna, Universidad de La Laguna.

León De Pinelo, A. (1971): Anales de Madrid (desde el año 447 al de 1658), transcripción, notas y ordenación cronológica de Pedro Fernández Martín, Madrid, Instituto de Estudios Madrileños.

López García, J. M. (dir.) (1998): El impacto de la corte en Castilla. Madrid y su territorio en la época moderna, Madrid, Siglo XXI.

Losa Contreras, C. (1999): El concejo de Madrid en el tránsito de la Edad Media a la Edad Moderna, Madrid, Dykinson.

MARTINEz RuIz, J. I. (1992): Finanzas municipales y crédito público en la España Modema. La bacienda de la ciudad de Sevilla, 1528-1768, Sevilla, Ayuntamiento de Sevilla. 
PARDO, J. (1984): «Constitución municipal y constitución de rentas: “censos" y deuda del concejo de Burgos, 1476-1510 ca.», en Anuario de Historia del Derecho Español, t. LIV, pp. 599-612.

PÉREZ, J. (19997): La revolución de las Comunidades de Castilla (1520-1521), Madrid, Siglo XXI.

Rerier, D. S., y Ballesteros, E. (1993): «Precios y salarios en Castilla La Nueva: la construcción de un índice de salarios reales, 1501-1991», en Revista de Historia Económica, año XI, núm. 1 (1993), pp. 101-151.

RuIz IBÁÑEz, J. I. (1995): Las dos caras de Jano. Monarquia, ciudad e individuo. Murcia, 1588-1648, Murcia, Ayuntamiento-Universidad de Murcia.

SAinZ DE BuJANDA, F. $\left(1993^{10}\right)$ : Lecciones de derecho financiero, Madrid, Universidad Complutense.

SchulzE, W. (1996): «Émergence et consolidation de "l'État" Fiscal. I. Le XVle siècle», en R. BONNEY, R. (dir.), Systèmes économiques et finances publiques, Paris, PUF, pp. 257-276.

Thompson, I. A. A. (2000): «Public expenditure and political unity: Spanish Monarchy and European Union», en A. M. Bernal (edit.), Dinero, moneda y crédito en la Monarquía Hispánica, Madrid, Marcial Pons, pp. 879-888.

Tomás y Valiente, F. (1982): «La Diputación de las Cortes de Castilla (1525-1601)», en Gobierno e instituciones en la España del Antiguo Régimen, Madrid, Alianza Universidad, pp. 37-150.

UlLOA, M. $\left(1977^{2}\right)$ : La hacienda real de Castilla en el reinado de Felipe II, Madrid, Fundación Universitaria.

Yun Casalilla, B., y Comín, F. (2001): «Spain: from a composite monarchy to a national State, 1500-1900», en The Formation and Efficacy of Fiscal States in Europe and Asia, 1500-1914. Reunión celebrada en el Instituto de Estudios Fiscales en el 21-23 de junio.

Zabala Aguirre, P. (2000): Las alcabalas y la bacienda real de Castilla, Santander, Universidad de Cantabria. 